\title{
CINTA LINGKUNGAN SEBAGAI IMPLEMENTASI NILAI KARAKTER RELIGIUS: SUATU PERSPEKTIF BERDASARKAN EFESUS 5:1-21
}

\author{
Dwi Indarti Hutami Dewi*1, Setiya Aji Sukma ${ }^{2}$ \\ ${ }^{1,2}$ Sekolah Tinggi Teologi Excelsius \\ *dwiindarti@sttexcelsius.ac.id
}

\begin{abstract}
The world of education is increasingly confronted with a variety of increasing challenges and demands that education increasingly innovate in developing educational products. Research Objectives: What is the meaning of Environmental Care according to the Bible and experts? Does Environmental Care attitude support the effectiveness of learning? What is the perspective of Ephesians 5: 1-21 regarding Environmental Care as an Implementation of Religious Character Values? The research method used is exposition and literature research. The results of the study are: (1) the meaning of caring for the environment is the dimension of the space into which the learning activities take place, caring for the environment is everyone's participation. This needs to be instilled for students to grow generations who can take part in the framework of preserving the environment or social environment. (2) environmental care attitude (in family, school, and community) is realized through obedience in realizing environmental preservation efforts. Because this must be based on, because with agreement, humans will automatically have a sense of caring. The environment as a container for the formation of a person's character. (3) Christ is the only example in terms of what is agreed, Christians must understand Christ on each other's beliefs, then apply Christ's love for the environment, so as to create a healthy and loving environment in the world of Indonesian education.
\end{abstract}

Keywords: religious; education; environment

\begin{abstract}
Abstrak
Dunia pendidikan semakin hari semakin dihadapkan dengan berbagai tantangan yang mempersulit dan menuntut supaya pendidikan semakin berinovasi dalam mengembangkan produk pendidikan. Tujuan penelitian: Apakah makna Cinta Lingkungan menurut Alkitab dan para ahli? Apakah sikap Cinta lingkungan menunjang efektifitas pembelajaran? Bagaimanakah perspektif Efesus 5:1-21 mengenai Cinta Lingkungan sebagai Implementasi Nilai Karakter Religius? Metode penelitian yang digunakan adalah eksposisi dan penelitian literature. Hasil penelitian adalah: (1) makna cinta lingkungan adalah mengasihi dimensi ruang yang menjadi tempat melakukan kegiatan pembelajaran, cinta lingkungan adalah kewajiban semua orang. Hal ini perlu ditanamkan kepada peserta didik agar bertumbuh menjadi generasi yang dapat ambil bagian dalam rangka melestarikan lingkungan alam maupun lingkungan pergaulan. (2) sikap cinta lingkungan (dalam keluarga, sekolah, dan masyarakat) diwujudkan melalui ketaatan dalam mewujudkan upaya pelestarian lingkungan. Ketaatan tersebut haruslah berdasarkan pada kasih, karena dengan mengasihi, manusia akan dengan otomatis memiliki rasa peduli. Lingkungan tersebut sebagai wadah pembentukan karakter seseorang. (3) Kristus adalah satu-satunya teladan dalam hal mengasihi, orang Kristen harus memahami kehendak Kristus atas dirinya masing-masing, lalu menerapkan kasih Kristus kepada lingkungan, agar tercipta lingkungan yang sehat dan penuh kasih di dunia pendidikan Indonesia.
\end{abstract}

Kata Kunci: religious; pendidikan; lingkungan 


\section{PENDAHULUAN}

Dunia pendidikan semakin hari semakin dihadapkan dengan berbagai tantangan yang mempersulit dan menuntut supaya pendidikan semakin berinovasi dalam mengembangkan produk pendidikan, metode pembelajaran, dan melahirkan lulusan-lulusan yang berprestasi di bidangnya masing-masing. Mencintai lingkungan merupakan salah satu upaya yang menjadi pilihan dalam mengembangkan proses pendidikan.

Keberhasilan tercapainya suatu tujuan pendidikan di sekolah dipengaruhi oleh banyak faktor, salah satunya ialah faktor lingkungan, dalam hal ini adalah lingkungan pendidikan. Pendidikan memiliki tiga pilar yaitu pendidikan keluarga, pendidikan sekolah dan pendidikan masyarakat. Menurut Zakiah Daradjat, lingkungan dibedakan menjadi dua, yakni lingkungan pendidikan di dalam sekolah dan lingkungan pendidikan di luar sekolah, yang meliputi lingkungan keluarga, lingkungan asrama, perkumpulan remaja, dan lingkungan kerja. ${ }^{1}$ Seorang pendidik memiliki peranan yang signifikan dalam menghasilkan generasi yang berwawasan luas, santun dalam bersosialisasi dan mampu menerapkan pengetahuan yang didapatnya di tengah lingkungan masyarakat dunia.

Dewasa ini menguat kesadaran bahwa manusia dan lingkungannya semakin tak terpisahkan: lingkungan merupakan syarat mutlak kehidupan dan perkembangan manusia, sedangkan manusia sendiri pada gilirannya akan menyempurnakan dan memuliakan lingkungannya melalui kehadirannya, kerjanya dan pemikirannya.

${ }^{1}$ Sukarman, "Reaktualisasi Konsep Tri Pusat Pendidikan Ki Hajar Dewantara dalam Perspektif Pendidikan Islam Bagi Generasi Milenial" Jurnal Progress: Wahana Kreativitas dan Intelektualitas Vol. 5 No. 1 (2017):5.
Manusia dan lingkungan saling bergantung dan mempunyai masa depan bersama. Nahdi menguraikan bahwa sejak zaman sejarah nenek moyang bangsa Indonesia telah mengajarkan cinta lingkungan melalui berbagai kearifan lokal (basis sosioantropologis). ${ }^{2}$

Tujuan penulisan artikel ini adalah untuk menjawab pertanyaan-pertanyaan berikut: Apakah makna Cinta Lingkungan menurut Alkitab dan para ahli? Apakah sikap Cinta lingkungan menunjang efektifitas pembelajaran? Bagaimanakah perspektif Efesus 5:1-21 mengenai Cinta Lingkungan sebagai implementasi nilai karakter religius?

\section{METODE PENELITIAN}

Dalam penulisan karya ilmiah ini, penulis menggunakan metode penelitian kualitatif, dengan pendekatan eksposisi dan kajian literatur Alkitabiah di mana penulis mengadakan penelitian terhadap buku-buku serta melakukan eksplorasi internet yang mengkaji konsep cinta lingkungan.

\section{PEMBAHASAN}

\section{Makna Cinta Lingkungan menurut Alkitab dan Para Ahli}

Cinta lingkungan merupakan salah satu sub unit karakter dalam desain pendidikan karakter yang dicanangkan oleh Pemerintah. Gerakan Penguatan Pendidikan Karakter merupakan gerakan yang telah dicanangkan sejak tahun 2016 oleh Kemdibud sebagai langkah mewujudkan visi revolusi mental yang disampaikan oleh

${ }^{2}$ Khirjan Nahdi, Pendidikan dan Modernisasi Peradaban (Yogyakarta: Cakrawala, 2018), 164. 
Presiden Republik Indonesia Joko Widodo.

Pendidikan Karakter memiliki empat dimensi, yakni: olah hati (etik), olah pikir (literasi), olah rasa (estetik), dan olahraga (kinestetik). Olah hati menghasilkan individu yang memiliki kerohanian mendalam, beriman dan bertakwa. Olah pikir menghasilkan individu yang memiliki keunggulan akademis sebagai hasil pembelajaran dan pembelajar sepanjang hayat. Olah rasa menghasilkan individu yang memiliki integritas moral, rasa berkesenian, dan berkebudayaan. Olahraga menghasilkan individu yang sehat dan mampu berpartisipasi aktif sebagai warga negara. Kemdikbud memberikan uraian secara padat tentang Penguatan Pendidikan Karakter yang memiliki lima nilai karakter utama yang bersumber dari Pancasila. Lima nilai karakter tidak berdiri sendiri melainkan berinteraksi satu sama lain, antara lain: religius, nasionalisme, integritas, kemandirian dan kegotongroyongan. ${ }^{3}$

Oleh karena luasnya cakupan lima nilai karakter, maka penulis membatasi bahasan pada karakter religius. Nilai karakter religius mencerminkan keberimanan terhadap Tuhan yang Maha Esa yang diwujudkan dalam perilaku melaksanakan ajaran agama dan kepercayaan yang dianut, menghargai perbedaan agama, menjunjung tinggi sikap toleran terhadap pelaksanaan ibadah agama dan kepercayaan lain, hidup rukun dan damai dengan pemeluk agama lain. ${ }^{4}$ Cinta lingkungan termasuk dalam implementasi nilai karakter religius.

Terbentuknya karakter yang

${ }^{3}$ Kementerian Pendidikan dan Kebudayaan, Penguatan Pendidikan Karakter Jadi Pintu Masuk Pembenahan Pendidikan Nasional, diakses 29 Februari, 2020,

https://www.kemdikbud.go.id/main/blog/ 2017/07/penguatan-pendidikan-karakter-jadi-pintumasuk-pembenahan-pendidikan-nasional. paripurna sesuai dengan tujuan pendidikan nasional tidaklah mudah. Karakter yang diharapkan bersifat komprehensif, tidaklah dimaksudkan pada seorang individu terbentuk karakter religius tapi tidak cinta ilmu, disiplin tapi tidak cinta lingkungan, memiliki rasa ingin tahu tapi tidak menghargai karya orang lain, mengakui keberagaman tapi tidak menjalankan ajaran agamanya dengan baik, dan seterusnya.

Berdasarkan teori belajar dalam tulisan Dadan Rosana mengutip Karli dan Yuliaritiningsih, melalui pendekatan lingkungan akan menghasilkan pembelajaran yang bermakna, sikap verbalisme pelajar terhadap penguasaan konsep dapat diminimalkan, dan pemahaman pelajar akan membekas dalam ingatannya. Buah dari proses pendidikan dan pembelajaran akhirnya akan bermuara pada cinta lingkungan. ${ }^{5}$ Guru dapat menanamkan sikap cinta terhadap lingkungan dengan menjadikan lingkungan sekolah sebagai basis pembelajaran. Ini yang akan menumbuh-kembangkan budaya mengelola, memelihara, dan melestarikan lingkungan hidup. Manfaat keberhasilan pembelajaran akan terlihat manakala apa yang diperoleh dari pembelajaran dapat diaplikasikan dan diimplementasikan dalam realitas kehidupan.

Berbicara tentang lingkungan, tidak terbatas pada lingkungan alam saja. Faktor lingkungan sosial juga berperanan dalam tumbuh kembang jasmani dan rohani manusia. Rasul Paulus menyoroti pentingnya umat Allah memperhatikan relasi mereka dengan lingkungan, baik

${ }^{4}$ Ibid.

${ }^{5}$ Dadan Rosana, “"Berbagai Model Dan Metode Pembelajaran Aktif Kreatif Dan Inspiratif Bagi Keberhasilan Belajar Siswa," last modified March 29, 2020,

http://staffnew.uny.ac.id/upload/132058092/lainlain/ makalah-ppsb-man-3.pdf. 
lingkungan keluarga (Ef. 5:21-6:4; Kol. 3:18-21; 1 Ptr. 3:1-7), lingkungan pendidikan (2 Tim. 2:2: Kis. 19:8-9), maupun lingkungan masyarakat (1 Kor. 15:33; Gal. 6:1-10).

Tidak ada keraguan terhadap karakteristik visi universalis kepribadian Rasul Paulus. Bagi Rasul Paulus "tidak ada orang Yahudi atau orang Yunani, tidak ada hamba atau orang merdeka, tidak ada lakilaki atau perempuan, karena kamu semua adalah satu di dalam Kristus Yesus" (Gal. 3:28). Bahkan, situasi historis dan budaya pada zaman dan lingkungannya tidak bisa tidak memiliki pengaruh terhadap keputusan dan karyanya. Paulus dikenal sebagai "manusia dari tiga budaya", dengan mempertimbangkan latar belakang Yahudi, bahasa Yunani, dan hak prerogatifnya sebagai warga negara Romawi. Pendidikan Paulus di rumah dan di sinagog di bawah didikan Gamaliel, observasinya terhadap lingkungan, pengalaman pertobatannya, pikiran kreatifnya, dan yang paling utama pewahyuan ilahi yang diterimanya telah membentuk teologinya.

Dalam perikop "Hidup sebagai anakanak terang” (Ef. 5:1-21), penulis bertujuan memahami perspektif Paulus tentang bagaimana seharusnya cara orang Kristen hidup di tengah lingkungannya, sehingga pada akhirnya terdorong untuk memedulikan lingkungannya. Penulis menggunakan hasil kajian biblika dari Efesus 5:1-21 sebagai dasar pengajaran tentang cinta lingkungan bagi para guru Pendidikan Agama Kristen agar dapat diajarkan kepada peserta didiknya.

\footnotetext{
${ }^{6}$ Dian Widianti, Ensiklopedi Cinta (Bandung: DAR! Mizan, 2007), 37.

${ }^{7}$ Duane Schultz, Psikologi Pertumbuhan: Model-Model Kepribadian Sehat (Yogyakarta: Kanisius, 1991), 67. ${ }^{8}$ Ibid.
}

Definisi Istilah

$$
\text { Makna kata "cinta" maupun }
$$
"lingkungan" bukan lagi merupakan hal yang asing di telinga pembaca, meski demikian terkadang masing-masing pribadi memiliki definisi dan persepsi yang tidak jarang tidak selaras dengan maksud yang penulis harapkan, oleh sebab itu, penulis mencantumkan pengertian "cinta" maupun "lingkungan" berdasarkan definisi beberapa ahli.

\section{Definisi Cinta}

Definisi cinta cukup dinamis dan fleksibel. Seorang psikolog asal Amerika Serikat, Ashley Montagu, memandang cinta sebagai sebuah perasaan memerhatikan, menyayangi dan menyukai yang mendalam. ${ }^{6}$ Duane Schultz berpandangan bahwa cara yang sehat untuk berhubungan dengan dunia ialah melalui cinta. Cinta memuaskan kebutuhan akan keamanan dan juga menimbulkan perasaan integritas dan individualitas. $^{7}$

Perasaan cinta mendorong seseorang melakukan yang terbaik bagi objek yang dicintainya. Erich Fromm mendefinisikan cinta meliputi cinta orang tua terhadap anak, cinta kepada diri sendiri, dan dalam pengertian yang lebih luas, solidaritas dengan semua orang dan mencintai mereka. ${ }^{8}$

Ada empat elemen dasar untuk mewujudkan cinta kasih, yaitu: perhatian, tanggung jawab, rasa hormat dan pengetahuan. Keempat elemen dasar tersebut muncul semua secara seimbang dalam pribadi yang mencintai. ${ }^{9}$ Jika seseorang mengatakan bahwa ia mencintai anak maka sudah seharusnya ia mengasuh

\footnotetext{
${ }^{9}$ Erich Fromm, Seni Mencintai (Yogyakarta: BASABASI, 2018), 40.
} 
dan bertanggung jawab pada si anak. Tanggung jawab dan pengasuhan tanpa rasa hormat sesungguhnya dan tanpa rasa ingin mengenal lebih dalam akan menjerumuskan para orang tua, guru, rohaniwan, dan individu lainnya pada sikap otoriter. Mustahil seseorang mengatakan bahwa ia menyintai lingkungannya, namun dalam kehidupan sehari-hari ia membuang sampah sembarangan.

\section{Definisi Lingkungan}

Definisi berikutnya yang perlu dicermati adalah kata "lingkungan". Seringkali istilah lingkungan hanya dibatasi pada lingkungan alam, sehingga muncullah berbagai gerakan pelestarian lingkungan. Akan tetapi sesungguhnya istilah lingkungan meliputi seluruh kondisi dalam dunia ini yang dalam cara-cara tertentu memengaruhi tingkah laku manusia, pertumbuhan, perkembangan atau life processes, kecuali gen-gen dan bahkan gen-gen dapat pula dipandang sebagai menyiapkan lingkungan bagi gen yang lain. ${ }^{10}$

Lingkungan sendiri memiliki pengertian yang luas. Selain bermakna tempat, lingkungan juga mengacu pada kondisi sosial, pergaulan dan tingkat pengertian yang dimiliki golongan, dimana seseorang tinggal, beraktifitas, menjalani hidupnya. PB memaparkan tentang keteladanan untuk mengasihi lingkungan, salah satunya adalah Surat Efesus 5:1-21. Melalui perenungan yang tidak singkat, penulis menemukan bahwa dalam perikop tersebut Paulus menyiratkan nasehat agar jemaat menjaga dan mencintai lingkungannya, secara spesifik kepada sesama di lingkungannya.

Lingkungan juga diartikan sebagai segala sesuatu yang mengitari kehidupan,

${ }^{10}$ Ngalim Purwanto, Psikologi Pendidikan (Bandung: Remaja Rosdakarya, 2000), 28. baik berupa fisik seperti alam jagad raya dengan segala isinya, maupun berupa nonfisik, seperti suasana kehidupan beragama, nilai-nilai dan adat-istiadat yang berlaku di masyarakat, ilmu pengetahuan, dan kebudayaan yang berkembang, kedua lingkungan tersebut hadir secara kebetulan, yakni tanpa diminta dan direncanakan oleh manusia. ${ }^{11}$ Jadi, lingkungan adalah segala sesuatu baik fisik maupun nonfisik yang hadir dan memengaruhi manusia. Lingkungan memiliki peran penting dalam mewujudkan kepribadian manusia.

Berdasarkan definisi kedua istilah tersebut dapat disimpulkan bahwa cinta lingkungan adalah suatu tindakan memerhatikan, menyukai dan memberikan yang terbaik dan penuh tanggung jawab terhadap lingkungan fisik dan nonfisik yang mengitari kehidupan seseorang. Menyintai lingkungan tidak serta merta timbul dalam diri seseorang melainkan tindakan terus menerus yang ditanamkan dalam sanubari manusia.

Jenis-jenis Lingkungan

Lingkungan dalam konteks pendidikan, terdiri dari tiga: pertama lingkungan keluarga, kedua lingkungan sekolah, dan ketiga lingkungan masyarakat. Mansur mengemukakan bahwa ketiga lingkungan itu pada dasarnya tidak dapat dipisahkan, karena lingkungan sekolah sebagai kepanjangan dari lingkungan keluarga yang terikat dalam batasan waktu, dan lingkungan masyarakat merupakan samudra dari aliran lingkungan keluarga atau pun sekolah, karena masyarakat merupakan kumpulan dari individu-individu yang hidup bersama dalam rentang waktu yang relatif lama, dan diikat oleh satu tujuan yang

${ }^{11}$ Abuddin Nata, Ilmu Pendidikan Islam (Jakarta: Kencana Penanda Media Grup, 2010), 290. 
sama. ${ }^{12}$ Perlu ditanamkan kesadaran pada peserta didik bahwa dirinya tidak hanya hidup bagi diri sendiri melainkan juga untuk orang lain.

\section{Lingkungan Keluarga}

Lingkungan yang paling besar pengaruhnya bagi pembentukan pendidikan anak adalah lingkungan keluarga. Orang tua memiliki peranan yang sangat penting dalam mengembangkan seluruh potensi yang ada dalam diri anak. Cara yang diterapkan oleh orang tua dalam mendidik anak mereka di rumah juga akan memberikan kontribusi bagi kehidupan anak di masa depan. Metode pendidikan yang diterapkan antara orang tua satu dengan orang tua yang lain biasanya juga berbeda. Subianto berpendapat bahwa ayah dan ibu adalah satu-satunya teladan yang pertama bagi anak-anaknya dalam pembentukan kepribadian, begitu juga anak yang secara tidak sadar mereka akan terpengaruh, maka kedua orang tua di sini berperan sebagai teladan bagi mereka baik teladan pada tataran teoritis maupun praktis. ${ }^{13}$

Rumah atau keluarga merupakan lembaga pendidikan tertua, bersifat informal yang pertama dan utama dialami anak. Orang tua bertanggung jawab memelihara, merawat, melindungi dan mendidik anak agar tumbuh dan berkembang dengan baik. Dalam tulisan Kusni Ingsih, dkk. disebutkan bahwa pendidikan keluarga berfungsi: 1) sebagai pengalaman pertama masa anak-

\footnotetext{
${ }^{12}$ Rosichin Mansur, "Lingkungan Yang Mendidik Sebagai Wahana Pembentukan Karakter Anak" Vicratina: Jurnal Pendidikan Islam 2, no. 2 (July 4, 2018): 34.

${ }^{13}$ Jito Subianto, "Peran Keluarga, Sekolah, Dan Masyarakat Dalam Pembentukan Karakter Berkualitas" Edukasia : Jurnal Penelitian Pendidikan Islam 8, no. 2 (September 26, 2013): 337, accessed June 28, 2020,

https://journal.iainkudus.ac.id/index.php/Edukasia/ar ticle/view/757.
}

anak; 2) menjamin kehidupan emosional anak; 3) menanamkan dasar pendidikan moral; 4) memberikan dasar sosial; dan 5e) meletakkan dasar-dasar pendidikan agama bagi anak. ${ }^{14}$

Sedangkan menurut Megawangi dalam buku Tridonanto, ada beberapa kesalahan orang tua dalam mendidik anak yang dapat memengaruhi perkembangan kecerdasan emosi anak sehingga berakibat pada pembentukan karakternya, yaitu: 1) kurang menunjukkan ekspresi kasih sayang baik secara verbal maupun fisik; 2) kurang meluangkan waktu yang cukup untuk anaknya; 3) bersikap kasar secara verbal, misalnya menyindir, mengecilkan anak, dan berkata-kata kasar; 4) bersikap kasar secara fisik, misalnya memukul, mencubit, dan memberikan hukuman badan lainnya; 5) terlalu memaksa anak untuk menguasai kemampuan kognitif secara dini; dan (6) tidak menanamkan "good character" kepada anak. $^{15}$

Berdasarkan pemikiran-pemikiran tersebut dapat disimpulkan bahwa lingkungan keluarga mengambil peranan terpenting dan utama dalam pendidikan karakter anak. Keteladanan orang tua dalam mendidik anak akan menumbuhkan kepribadian anak menjadi baik dan kuat hingga dewasa. Pola pendidikan yang salah dari orang tua akan menumbuhkan karakter anak yang cenderung negatif dan melukai hati bahkan fisik orang-orang di sekitarnya kelak.

\footnotetext{
${ }^{14}$ Kusni Ingsih, dkk., Pendidikan Karakter: Alat Peraga Edukatif Media Interaktif, 45.

${ }^{15}$ Al. Tridonanto, Menjadikan Anak Berkarakter (Jakarta: Elex Media Komputindo, 2013), 118.
} 


\section{Lingkungan Sekolah}

Lingkungan sekolah juga besar pengaruhnya bagi terbentuknya kepribadian seorang anak. Sekolah sebagai tempat anakanak belajar dan bermain dan sebagai tempat untuk anak bersosialisasi dengan orang lain. Pembentukan kepribadian anak juga dipengaruhi oleh teman-teman, guru dan warga sekolah. Prof. Dr. H. Sukiyat, M.Si., SH memaparkan bahwa anak mengalami perubahan dalam perilaku sosialnya setelah ia masuk sekolah. ${ }^{16}$ Di sekolah anak belajar menyesuaikan diri dengan lingkungan sosial yang baru yang memperluas keterampilan sosialnya. Selain itu anak mengenal berbagai ragam latar belakang dan belajar untuk menjalankan peranannya dalam struktur sosial yang dihadapinya di sekolah. ${ }^{17}$

Lembaga pendidikan memberikan pengajaran secara formal yang berbeda dengan pengajaran yang dilakukan dalam keluarga dan masyarakat. Sekolah adalah tempat mengajar dan belajar. Kegiatan belajar merupakan kegiatan yang paling pokok dalam proses pendidikan. Hal ini berarti bahwa berhasil atau tidaknya pencapaian tujuan pendidikan banyak bergantung kepada bagaimana proses belajar yang dialami oleh para peserta didik. Seseorang yang telah melalui proses belajar diharapkan akan mengalami perubahan tingkah laku. Perubahan tingkah laku yang dimaksud dapat berupa pengetahuan yang diperolehnya setelah melalui tahapan belajar. Belajar adalah suatu proses usaha yang dilakukan seseorang untuk memperoleh suatu perubahan tingkah laku yang baru secara keseluruhan, sebagai hasil pengalamannya sendiri dalam berinteraksi -

${ }^{16}$ Sukiyat, Strategi Implementasi Pendidikan Karakter (Surabaya: Jakad Media Publishing, 2020), 41.

${ }^{17}$ Ibid., 42. dengan lingkungannya.

Guru di lingkungan sekolah mengambil peran dalam membangun hubungan yang harmonis dengan anak didik, serta membentuk kepribadian anak didik. Guru sebagai pendidik dituntut tidak hanya pandai dalam menyampaikan materi, namun lebih menekankan pada pembentukan karakter peserta didik. Pada hakikatnya sekolah bukanlah sekedar tempat "transfer of knowledge" belaka. Fraenkel menjelaskan bahwa sekolah tidaklah semata-mata tempat di mana guru menyampaikan pengetahuan melalui berbagai mata pelajaran. ${ }^{18}$

Sekolah juga adalah lembaga yang mengusahakan usaha dan proses pembelajaran yang berorientasi pada nilai (value-oriented enterprise). Pembentukan karakter merupakan bagian dari pendidikan nilai (values education) melalui sekolah merupakan usaha mulia yang mendesak untuk dilakukan. Sekolah bertanggungjawab bukan hanya dalam mencetak peserta didik yang unggul dalam ilmu pengetahuan dan teknologi, tetapi juga dalam jati diri, karakter dan kepribadian. ${ }^{19}$

Berdasarkan berbagai paparan tersebut dapat disimpulkan bahwa lingkungan sekolah sebagai pusat belajar dan mengajar mengambil peranan dalam perubahan perilaku sosial anak didik. Guru, teman dan segenap warga sekolah berperanan dalam mendorong terbentuknya keterampilan sosial anak didik sehingga mencapai tahap keunggulan pengetahuan, jati diri, karakter dan kepribadiannya.

\footnotetext{
${ }^{18}$ Rianawati, Implementasi Nilai -Nilai Karakter Pada Mata Pelajaran (IAIN Pontianak Press, 2014), 5.

${ }^{19}$ Jack R Fraenkel, Helping Students Think and Value: An Analytic Approach (New Jersey: Prentice Hall, 1977), 1-2.
} 


\section{Lingkungan Masyarakat}

Hasbullah mengungkapkan bahwa masyarakat adalah wadah dan wahana pendidikan; medan kehidupan manusia yang majemuk. $^{20}$ Masyarakat merupakan komunitas moral yang berbagi tanggung jawab untuk pendidikan mengembangkan karakter yang setia dan konsisten kepada nilai dasar yang diusung bersama-sama.

Dalam lingkungan masyarakat terdapat sejumlah norma-norma yang ditaati bersama oleh seluruh anggota masyarakat. Masyarakat merupakan media bagi peserta didik dalam berinteraksi dan bersosialisasi dengan sesamanya. ${ }^{21}$ Menurut Simanjuntak dalam proses sosialisasi seorang individu dari masa anak-anak sampai masa tua selalu belajar pola-pola tindakan dalam interaksi dengan segala macam individu sekitarnya yang menduduki beraneka macam peranan sosial. $^{22}$

Di lingkungan masyarakat ini pun setiap manusia akan mendapat pengaruh yang sifatnya mendidik dari orang-orang yang ada di sekitarnya, baik teman sebaya maupun orang dewasa melalui interaksi sosial secara langsung atau tidak langsung. Begitu pula lingkungan budaya akan memberikan pengaruh pada tumbuhkembang anak, yang pada gilirannya ikut andil dalam terbentukya karakter anak. Selain memberikan pengaruh dan pengalaman pada manusia, lingkungan masyarakat juga memiliki peran dalam dunia pendidikan. ${ }^{23}$

Kepribadian yang dimiliki anak dan

${ }^{20}$ Hasbullah, Dasar - Dasar Ilmu Pendidikan (Jakarta: Raja Grafindo Persada, 2009), 55

${ }^{21}$ Amos Neolaka dan Grace Amialia A. Neolaka, Landasan Pendidikan Dasar Pengenalan Diri Sendiri Menuju Perubahan Hidup: Edisi Pertama (Depok: Kencana, 2015), 270.

${ }^{22}$ Yulia Siska, Geografi Sejarah Indonesia (Garudhawaca, 2018), 149, (yang dikutip dari Koentjaraningrat 1993:232). perilakunya terbentuk dalam proses yang panjang dan dalam waktu yang lama. Fillmore H. Sandford mengemukakan bahwa kepribadian adalah susunan yang unik dari sifat-sifat seseorang yang berlangsung lama. Sementara Allport mengatakan, kepribadian adalah susunan yang dinamis di dalam psikofisik (jasmanirohani) seseorang (individu) yang menentukan perilaku dan pikirannya yang berciri khusus. Lingkungan sebagai sumber pengetahuan dan pengalaman yang relatif menentukan terbentuknya suatu karakter atau kepribadian anak, bukan bawaan yang menentukan. ${ }^{24}$

Dengan demikian lingkungan yang mendidik adalah lingkungan yang baik, positif dan konstruktif dalam perkembangan anak. Lingkungan keluarga merupakan pendidikan utama dan pertama dalam menumbuh-kembangkan potensi anak, dan juga pembentukan pribadi atau karakter anak. Lingkungan sekolah sebagai peran pengganti lingkungan keluarga dalam mendidik anak yang tidak terlepas dari keterbatasan-keterbatasan yang dimilikinya dalam membentuk karakter anak. ${ }^{25}$

Lingkungan masyarakat melengkapi yang belum ada pada keluarga dan sekolah serta memiliki andil dalam pengembangan individu dan sosial yang cerdas dan berbudaya. Jadi, ketiga lingkungan yang mendidik baik lingkungan keluarga, sekolah maupun masyarakat adalah wadah pembentukan karakter seseorang sehingga dikemudian anak bisa memahami dan

100

${ }^{23}$ Hasbullah, Dasar-Dasar Ilmu Pendidikan,

${ }^{24}$ Arifin, Strategi Belajar Mengajar: Jurusan Pendidikan Kimia FPMIPA UPI (Bandung: Bumi Aksara, 2000), 166

${ }^{25}$ Made Aripta Wibawa, Siapakah yang Disebut Guru: Suatu Kajian Theologis dan Sosiologis (Denpasar: Panakom Pub., 2005), 93. 
menunjukkan eksistensi dirinya dalam kehidupan. Nilai-nilai yang hidup dalam masyarakat dan terbentuk dalam suatu sistem nilai menjadi sumber rujukan dalam pembentukan pribadi atau karakter anak lebih baik.

\section{Sikap Cinta Lingkungan sebagai Kunci Nyaman Belajar}

Kenyamanan dalam belajar tidaklah serta merta timbul dalam diri seorang peserta didik. Kenyamanan belajar di rumah dimulai dari dukungan keluarga dan lingkungan rumah yang aman dan terlindung. Cahaya, musik dan desain ruangan memengaruhi semangat belajar. Dalam suasana yang nyaman dan santai, seseorang baik yang masih kanak-kanak, remaja, maupun yang dewasa, dapat berkonsentrasi dengan sangat baik dan mampu belajar dengan mudah.

Kenyamanan belajar di sekolah diawali oleh persiapan situasi yang mencakup tempat, suasana ruangan kelas dan situasi umum. Suprihatiningsih mengemukakan dua hal yang berkaitan dengan kenyamanan belajar yaitu kenyamanan yang bersifat intern dan ekstern. Kenyamanan intern dapat berupa motivasi peserta didik terhadap tujuan pembelajaran yang ingin diraih peserta didik, dukungan orang tua dan lingkungan peserta didik. Kenyamanan ekstern berupa lingkungan belajar peserta didik. ${ }^{26}$ Suprihatiningsih menambahkan bahwa lingkungan belajar yang tidak nyaman misalnya tempat belajar yang hiruk pikuk karena dekat jalan raya atau pasar, dan dapat pula suasana ruangan yang panas karena pertukaran udara yang kurang. ${ }^{27}$

Oleh karenanya diperlukan suatu

${ }^{26}$ Suprihatiningsih, Perspektif Manajemen Pembelajaran Program Keterampilan (Yogyakarta: Deepublish, 2016), 26.

${ }^{27}$ Ibid. strategi dalam penataan lingkungan yang kondusif. Interaksi antarpelajar juga sangat dipengaruhi oleh suasana kelas yang indah dan nyaman. Kenyamanan dan keindahan terdiri atas kenyamanan psikis dan kenyamanan fisik. Kenyamanan psikis adalah kenyamanan kejiwaan (rasa aman, tenang, gembira, dan sebagainya) yang terukur secara subjektif (kualitatif). Kenyamanan fisik dapat terukur secara objektif (kuantitatif); yang meliputi kenyamanan spasial, visual, auditorial dan termal. $^{28}$

Lingkungan belajar yang indah berpengaruh positif pada sikap dan tingkah laku peserta didik terhadap kegiatan pembelajaran yang dilaksanakan. Tanggung jawab menjaga keindahan lingkungan belajar bukan hanya di pundak guru dan sekolah. Para peserta didik juga wajib menyintai lingkungan belajarnya. Pelibatan peserta didik dalam penataan ruangan akan menambah antusias belajar. Peserta didik akan merasa memiliki dan menjaga ruangannya dengan baik dan bersih. Cinta lingkungan sebagai kunci nyaman belajar, perlu dihidupi secara nyata oleh segenap pihak yang terlibat dalam proses pendidikan. Dalam hal ini peran utama dipegang oleh pendidik sebagai penyelenggara kegiatan pendidikan. Barulah kemudian dapat diterapkan kepada peserta didik, sehingga terjadi penanaman rasa cinta lingkungan yang menjadi dasar kenyamanan pada saat proses pembelajaran.

Joenaidy menyebutkan bahwa pembelajaran dengan menggunakan model cinta lingkungan memiliki beberapa manfaat: pertama, menanamkan karakter peduli, toleransi, menghargai sesama,

${ }^{28}$ Harjali, Penataan Lingkungan Belajar: Strategi untuk Guru dan Sekolah (Malang: Seribu Bintang, 2019), 97. 
bertanggung jawab, serta cinta lingkungan. Kedua, menciptakan suasana baru dalam belajar. Ketiga, menumbuhkan semangat peserta didik. Keempat, melatih kepekaan sosial peserta didik. $^{29}$ Dengan demikian, bahwa model kegiatan ini dapat diterapkan pada semua mata pelajaran. Kegiatan belajar di luar kelas dapat meningkatkan semangat dan motivasi belajar. Program penghijauan dan sadar lingkungan dapat mendorong tumbuhnya lingkungan yang asri dan nyaman bagi warga sekolah.

Sikap Keharmonisan Manusia dengan Lingkungan

Keharmonisan manusia dengan lingkungannya adalah maksud Allah sejak pada mulanya. Allah menciptakan dunia, menyatakan bahwa ciptaan-Nya itu baik, dan memercayakan pemeliharaannya pada manusia. Dalam suratnya kepada Timotius, Rasul Paulus menuliskan "Karena semua yang diciptakan Allah itu baik" (1 Tim. 4:4). Pernyataan ini menggemakan ayat Kitab Kejadian yang mengungkapkan kepuasan Allah pada setiap karya-Nya. Berkuasa atas ciptaan bagi umat manuia tak berarti manusia berhak untuk merusaknya. Manusia harus menyempurnakannya dan tidak mengubah dunia menjadi kekacauan.

Akibat dosa dan keserakahan manusia, lingkungan pun menjadi terancam. Kekayaan alam terus dieksploitasi, kurangnya kesadaran pelestarian lingkungan, dan penyimpangan moral telah merusak keharmonisan lingkungan sesama manusia. Menurut Hembing Wijayakusuma, dunia yang telah dirusak oleh keserakahan umat manusia itu sendiri, telah menimbulkan

\footnotetext{
${ }^{29}$ Abdul Muis Joenaidy, Guru Asyik, Murid Fantastik! (DIVA PRESS, 2018), 59.

${ }^{30}$ Hembing Wijayakusuma, Selamatkan umat manusia dari kebinasaan (Jakarta: Pustaka Kartini, 1995), 12.
}

ketimpangan pengertian bahwa alam adalah sumber eksploitasi bagi kepentingan manusia, yang pada selanjutnya merusak tatanan harmoni alam semesta yang berkaibat pula rusaknya tatanan harmoni hidup manusia itu sendiri. ${ }^{30}$

Akhir-akhir ini didapati bahwa rakyat melawan pemerintah, murid melawan guru, guru melanggar predikatnya sebagai "yang digugu dan ditiru" teladan bagi anak didiknya, anak melawan orang tua, dan lain sebagainya. ${ }^{31}$

Tatanan harmoni hidup manusia rusak apabila tidak mengerti hakikatnya yang sejati mengenai kehidupan dan lingkungannya. Seperti Paulus tuliskan dalam Roma 8:18-23, “...karena seluruh makhluk telah ditaklukan kepada kesiasiaan... tetapi dalam pengharapan...akan dimerdekakan dari perbudakan kebinasaan...". Roma 8:18-23 menjelaskan bahwa penebusan Kristus sebagai sumber dari pemulihan tatanan dan kemerdekaan orang percaya sebagai anak-anak Allah. Kesadaran bahwa maksud tujuan Allah akan alam semesta ini bukanlah kebinasaan dan kesia-siaan. Pengorbanan Kristus di kayu salib adalah untuk mengembalikan tatanan harmoni dan keselamatan atas semua mahkluk. Kesadaran itulah yang akan menumbuhkan cinta dalam diri manusia, khususnya "cinta lingkungan" seperti yang sedang dibahas dalam tulisan ini.

\section{Implementasi Nilai Karakter Religius berdasarkan Efesus 5:1-21}

Hidup sebagai anak-anak terang, sebagaimana judul perikop yang diberikan LAI untuk Efesus 5:1-21, adalah bentuk

\footnotetext{
${ }^{31}$ Suyanto dan Asep Jihad, Menjadi Guru Profesional: Strategi Meningkatkan Kualifikasi dan Kualitas Guru di Era Global (Jakarta: Penerbit Erlangga, 2013), 175.
} 
implementasi yang penulis harapkan dari kesadaran peserta didik terhadap kecintaan mereka akan lingkungan.

\section{Taat terhadap Aturan sebagai Wujud Cinta Lingkungan}

Tidak dapat dipungkiri, sebagian peserta didik sulit menaati peraturan. Bahkan ada sebagian orang yang membuat pernyataan bahwa peraturan ada untuk dilanggar, sebab kecenderungan manusia yang sangat mendasar, yaitu selalu merasa tidak puas dan penasaran. Secara naluri semakin seseorang dilarang melakukan sesuatu justru semakin merasa ingin untuk melakukan larangan tersebut. Di dalam penyelenggaraan kegiatan pendidikan, kedisiplinan belajar harus diutamakan. Menurut Moeliono, disiplin adalah ketaatan (kepatuhan) pada peraturan tata tertib, aturan, atau norma dan lain sebagainya. ${ }^{32}$

Disiplin peserta didik dalam belajar dapat dilihat dari ketaatan (kepatuhan) peserta didik terhadap aturan (tata tertib) yang berkaitan dengan kegiatan belajar mengajar di sekolah. Suatu peraturan terdiri dari dua hal mendasar, larangan dan himbauan untuk melaksanakan suatu tindakan yang harus ditaati. Akan ada orang yang berusaha menaati suatu peraturan, dengan berbagai alasan dibalik perlakuan tersebut. Namun sebaliknya, akan selalu ada pula orang yang dengan beragam alasannya pula berusaha melanggar segala peraturan yang ada tersebut. Menghadapi situasi yang sedemikian, seseorang seringkali tidak sadar bahwa terjadinya hal tersebut merupakan akibat dari perbedaan motivasi dan perspektif dalam memandang dan

${ }^{32}$ M. Anton Moeliono, Tata Bahasa Baku Bahasa Indonesia (Jakarta: Balai Pustaka, 1993), 208.

${ }^{33}$ John Taylor, Greek to GCSE: Part 2: Revised Edition for OCR GCSE Classical Greek (91) (Bloomsbury Publishing, 2016), 119. melaksanakan peraturan tersebut. Bagi pihak yang merasa peraturan ada untuk mengekang dirinya, ia akan cenderung menolak dan melawan aturan tersebut bagaimanapun caranya. Sedangkan bagi pihak yang merasa peraturan ada untuk membawa dirinya pada hal mendatangkan keberuntungan pada diriya, maupun menjauhkan hal-hal yang buruk terjadi pada dirinya, maka ia akan serta-merta melaksanakan aturan tersebut dengan penuh kerelaan. Ia sadar, bahwa adanya suatu peraturan tersebut, bukan untuk mencelakainya.

Melalui ayat pertama dan kedua di Efesus pasal kelima ini, Paulus menunjukkan bahwa sebagai anak-anak terang, menjadi penurut-penurut Allah memiliki dua konsep dasar. Pertama, hidup sebagai anak-anak yang kekasih artinya untuk dapat menaati suatu aturan yang ada seseorang harus memahami bahwa peraturan tersebut diadakan atas dasar kasih. Dengan kata lain, peraturan tersebut ada demi kebaikan dirinya, sehingga seseorang akan memperoleh suatu keuntungan apabila ia melaksanakannya. Kedua, agar seseorang tidak merasa terbebani dalam melaksanakan suatu aturan, ia harus dapat menerima aturan tersebut sebagai upaya perwujudan kasihnya terhadap orang-orang yang dikasihinya agar tetap aman dan memberikan perlindungan terhadap mereka dengan cara aturan tersebut. Dengan demikian akan terbangun kerelaan untuk melaksanakan aturan tersebut. Berkaitan hal tersebut, maka Efesus 5:1 berbunyi "jadilah penurut-penurut Allah." Kata "jadilah" dari kata Yunani ginesthe berbentuk present middle (deponent) imperative. ${ }^{33}$ Modus deponent 
menunjukkan bahwa tindakan menuruti perintah yang harus dilakukan karena timbul dari kesadaran pelaku, bukan sekadar menuruti perintah karena diharuskan oleh pihak lain.

Kata benda "peniru" berasal dari kata jamak Yunani mimetai. Seorang peniru Tuhan didefinisikan sebagai orang yang (1) mengampuni dan (2) hidup dalam kasih dan tidak mementingkan diri sendiri seperti Yesus. Tindakan-tindakan ini membangun dan memelihara kesatuan (Ef. 4:2-3). Orang percaya harus berjuang untuk kebaikan bersama sebagai tubuh Kristus, bukan hak istimewa, atau kebebasan individu (Ef 4:3). Ungkapan mimetai yang digunakan oleh Paulus adalah ungkapan tentang calon orator (ahli pidato) Yunani. Seorang calon orator harus memperhatikan teori, meniru atau meneladani dan praktik. Anak-anak Allah harus berlatih hidup baik menurut teladan Allah, demikian halnya peserta didik harus menurut teladan Allah, taat pada orang tua dan guru yang mendidiknya. Selain itu peraturan, tata tertib atau norma pergaulan penting untuk ditaati. Peraturan di sekolah diadakan untuk membentuk kedisiplinan dan ketangguhan siswa. Peserta didik perlu meniru atau meneladani yang baik, dan sebaliknya meninggalkan karakter buruk yang mungkin selama ini dimilikinya.

Frasa berikutnya yakni "seperti anakanak yang kekasih.” Orang-orang percaya dipanggil melalui sebutan teologis yang sama signifikannya seperti Yesus (Ef. 1:4-6). Orang percaya harus mencerminkan karakteristik Allah. Yesus memulihkan gambar Allah dalam manusia yang rusak dalam kejatuhan di Kejadian 3. Oleh karena kasih-Nya yang besar, bahkan Yesus rela mati guna menebus dosa manusia.

Dalam Efesus 5:2 terdapat perintah "hiduplah dalam kasih." Kata kerja "hiduplah" berbentuk present active imperative, dari kata harfiah Yunani peripateite "berjalanlah." yang merupakan metafora alkitabiah dari gaya hidup (Ef. $4: 1,17 ; 5: 2,15)$. Kekristenan adalah sebuah keputusan awal yang diikuti oleh gaya hidup pemuridan. Perintah "hiduplah dalam kasih" harus ditaati dalam lingkungan keluarga, sekolah dan masyarakat.

Berdasarkan berbagai paparan yang telah disampaikan, wujud cinta lingkungan dapat terlihat melalui ketaatan pada peraturan, tata tertib atau norma. Cinta lingkungan tidak akan tercipta apabila peserta didik masih bersikap acuh terhadap peraturan yang diadakan baik dalam kegiatan belajar maupun dalam menjaga lingkungan. Ketaatan haruslah berdasarkan pada kasih, karena dengan mengasihi, manusia akan dengan otomatis memiliki rasa peduli.

\section{Lingkungan yang Sehat Menunjang Perkembangan Karakter Bijak}

Dari Surat Efesus pasal kelima ayat 3-10, pembaca diingatkan mengenai banyak hal oleh Paulus, antara lain untuk menjauhi pergaulan yang cemar dan sesat. “...karena hal-hal yang demikian mendatangkan murka Allah atas orang-orang durhaka". Bahkan pada ayat yang ketujuh dengan tegas Paulus melarang umat Allah untuk berkawan dengan orang-orang yang melakukan tindakan tersebut. Dari hal ini cukup jelas bahwa Paulus mengingatkan jemaat di Efesus, untuk menjaga lingkungan pergaulannya, agar jangan mereka tersesat oleh karena terlibat dalam pergaulan di lingkungan yang buruk.

Paulus menunjukkan hal-hal yang perlu dilakukan oleh umat Allah dalam menghadapi situasi yang demikian jahat itu. Hal pertama yang dapat diambil dari ayat 310 misalnya, “..percabulan dan rupa-rupa kecemaran atau keserakahan disebut sajapun 
jangan di antara kamu.." Frase 'disebut sajapun jangan' merupakan kunci yang sangat penting. Frase ini menjelaskan dengan sangat lugas bahwa hal-hal buruk yang dilakukan oleh orang-orang yang berbuat kejahatan tidaklah baik untuk diperdengarkan di lingkungan. Abineno menafsirkan larangan Paulus itu mencakup segala macam kejahatan, baik kejahatan dalam bentuk perkataan (percakapan) seperti yang disebut dalam ayat 4 "perkataan yang kotor, yang kosong atau yang sembrono," maupun kejahatan dalam bentuk perbuatan seperti disebut dalam ayat 3 "percabulan dan rupa-rupa kecemaran atau keserakahan." Semuanya itu tidak pantas (ha ouk anèken), tidak layak mereka lakukan sebagai anggotaanggota tubuh Kristus. ${ }^{34}$ Pada ayat 12 Paulus menambahkan bahwa dengan menyebutkan atau mempercakapkan kejahatan-kejahatan yang dimaksud itu memalukan. Tidaklah bijak mengucapkan hal-hal yang kotor dan memalukan kepada orang lain.

Beberapa bulan terakhir banyak terjadi kasus perundungan yang dilakukan oleh teman-teman sekolah. Ada peserta didik yang tertekan jiwanya bahkan ada yang mengalami cacat fisik akibat perundungan. Kasus berikutnya yang masih banyak dijumpai adalah seks bebas di kalangan remaja. Penelitian yang dilakukan oleh Reckitt Benckiser Indonesia terhadap 500 remaja di lima kota besar di Indonesia menemukan, 33 persen remaja pernah melakukan hubungan seks penetrasi. Dari hasil tersebut, 58 persennya melakukan penetrasi di usia 18 sampai 20 tahun. Selain itu, para peserta survei ini adalah mereka yang belum menikah. ${ }^{35}$

\footnotetext{
${ }^{34}$ J.L.Ch. Abineno, Tafsiran Alkitab: Surat Efesus (Jakarta: Gunung Mulia, 2003), 147.

${ }^{35}$ Giovanni Dio Prasasti, "Riset: 33 Persen Remaja Indonesia Lakukan Hubungan Seks Penetrasi Sebelum Nikah," Liputan6.com, diakses 20 Maret 2020 ,
}

Kementerian Kesehatan RI melaporkan hasil survei bahwa di Indonesia, ada sekitar $4,5 \%$ remaja laki-laki dan $0,7 \%$ remaja perempuan usia 15-19 tahun yang mengaku pernah melakukan seks pranikah. Pada remaja usia 15-19 tahun, proporsi terbesar berpacaran pertama kali pada usia 15-17 tahun. Sekitar 33,3\% remaja perempuan dan $34,5 \%$ remaja laki-laki yang berusia 15-19 tahun mulai berpacaran pada saat mereka belum berusia 15 tahun. Pada usia tersebut dikhawatirkan belum memiliki keterampilan hidup (life skills) yang memadai, sehingga mereka beresiko memiliki perilaku pacaran yang tidak sehat antara lain melakukan hubungan seks pra nikah. ${ }^{36}$

Lingkungan keluarga dan sekolah haruslah menjadi lingkungan yang sehat bagi perkembangan jiwa anak. Menyintai lingkungan dapat dimaknai sebagai peduli pada lingkungan sekitar. Sikap permisif dan ketidakdekatan orang tua dan anak secara emosional berdampak tidak baik terhadap komunikasi interpersonal. Penting bagi orang tua untuk peduli pada anak bukan hanya masalah materi saja, tetapi juga peduli pada religiusitas dan moral anak. Pendidikan agama sangat penting ditanamkan sejak dini dari lingkup keluarga. Ciri-ciri anak yang memiliki religiusitas yang tinggi pada umumnya dapat terlihat dari tingkah laku, sikap dan perkataannya. Ketaatannya pada ajaran agama akan mengendalikan aktivitasnya di lingkungan sekolah dan masyarakat. Selain itu faktor teman sebaya juga cukup memengaruhi perilaku remaja. Oleh karenanya kepedulian orang tua kepada anak dan guru kepada peserta didik, akan

https://www.liputan6.com/health/read/4016841/riset33-persen-remaja-indonesia-lakukan-hubunganseks-penetrasi-sebelum-nikah\#.

36"Reproduksi Remaja," Kementerian Kesehatan RI. Pusat Data dan Informasi. J Infodatin, diakses 20 Maret 2020, https://www.depkes.go.id. 
sangat diharapkan sebagai salah satu wujud menyintai lingkungan.

Hal kedua terlihat dalam ayat 7 pada frase "janganlah kamu berkawan dengan mereka." Ayat ini tidak boleh dimaknai untuk tidak berkawan dengan orang-orang yang berbeda latar belakang budaya, ras dan agama, melainkan larangan untuk berkawan dengan para pembuat kejahatan sebagaimana disebut dalam ayat 3-6. Kata "berkawan" berasal dari kata Yunani summetokhoi yang berarti "berbagi dengan," "mengambil bagian," atau "berhubungan dengan." Umat Allah disebut sebagai anakanak Allah yang telah dikuduskan melalui pengorbanan Yesus Kristus di kayu salib. Tindakan pengudusan yang merupakan inistiatif dari Allah melayakkan umat Allah disebut sebagai “orang-orang kudus" (ay. 3). Meskipun demikian, umat Allah harus tetap hidup di dalam kekudusan dan tidak mengambil bagian dalam tindakan-tindakan kejahatan.

Dalam 1 Korintus 15:33 disebutkan "Janganlah kamu sesat: Pergaulan yang buruk merusakkan kebiasaan yang baik." Banyak orang Kristen takut anak-anaknya mendapatkan pengaruh buruk dari lingkungan sekuler sehingga mengurung mereka agar tidak terpapar dengan pikiranpikiran yang tidak sesuai dengan Injil. Padahal seharusnya mereka mengajar anakanak untuk bisa memilih dan memilah dengan bijaksana dan benar. Pertemanan peserta didik dengan para pembuat kejahatan, dalam pengertian turut ambil bagian dalam kejahatannya, tentu akan berakibat pada perubahan pola pikir dan pertumbuhan jiwanya. Di lingkungan keluarga, seorang anak yang dididik orang tuanya untuk mencuri akan berakibat buruk hingga masa dewasanya, sebab jiwa dan kepribadiannya telah rusak sejak dini. Firman Allah mendorong umat-Nya supaya memberitakan Injil kepada jiwa-jiwa yang tersesat ini.

Paulus mendorong umat Allah agar memiliki kebiasaan-kebiasaan yang baik. Kebiasaan pertama adalah mengucap syukur (ay. 4). Hal bersyukur sering dianggap remeh oleh sebagian besar orang, tetapi Paulus menegaskan sekali lagi perintah Allah tentang pengucapan syukur dalam ayat 20 yang menyebutkan "Ucaplah syukur senantiasa atas segala sesuatu dalam nama Tuhan Yesus Kristus kepada Allah dan Bapa." Pengucapan syukur dalam nama Tuhan Yesus Kristus mengandung makna mengucap syukur dalam iman. Jadi, bukan asal-asalan. Ada kesadaran iman bahwa Yesus Kristus adalah mediator kepada Allah Bapa di hari penghakiman. Kebiasaan kedua yang harus dimiliki setiap orang percaya adalah menguji "apa yang berkenan kepada Tuhan" (ay. 10). Kata "menguji” berasal dari kata Yunani dokimazō yang memiliki makna "membuktikan" sebagaimana dalam terjemahan KJV "prove". Umat Allah didorong untuk membuktikan perilaku dan karakter yang baik, bukan sekadar memperkatakan atau mengajarkan. Harus ada konsistensi antara kata dan perbuatan. NAS menerjemahkan kata dokimazo "try to learn" yang dimaknai sebagai usaha untuk mempelajari segala sesuatu yang berkenan kepada Allah.

Pengetahuan diperoleh baik dari orang tua, guru maupun rohaniwan. Tindakan menguji dalam filsafat pendidikan merupakan bagian dari fungsi kritik. ${ }^{37}$ Guru menuntun para peserta didik dapat berpikir kritis dalam segala hal, termasuk ketika menerima setiap materi yang diajarkan oleh gurunya di lingkungan sekolah. Perintah

${ }^{37}$ M. Anwar, Filsafat Pendidikan (Jakarta: Kencana, 2015), 60. 
"ujilah" ini yang dalam dunia pendidikan sering terlewat dalam pengajaran, sehingga peserta didik hanya terbiasa duduk diam tanpa perlawanan meskipun bisa saja ada hal yang keliru dalam penyampaiannya oleh guru. Dengan menguji segala sesuatu, diharapkan peserta didik dapat tergugah semangatnya dalam mempelajari setiap materi ajar yang disampaikan oleh guru di kelas.

Pada ayat 8 terdapat perbandingan antara yang dahulu (ête) dan yang sekarang (nun) dan antara kegelapan (skotos) dan terang $(f \overline{o s})$. Perbedaan yang bersifat kontras ini menunjukkan ketegasan kehendak Allah. Allah menghendaki umat-Nya menjadi anak-anak terang. Dalam konteks pembelajaran kata "dahulu" sebagai masa sebelum seseorang memperoleh pendidikan dan kata "sekarang" untuk dimaknai sebagai kondisi saat ini setelah seseorang memperoleh pendidikan, yang tentunya membawa perubahan sikap, perilaku dan pola pikir dalam menyikapi segala situasi dalam kehidupan. Kemudian, diperjelas lagi dengan kegelapan dan terang, hal ini tepat sebagaimana halnya kehidupan seseorang sebelum mengenyam pendidikan, ia hidup dalam kegelapan sehingga ada istilah yang ditujukan pada seorang anak yang putus sekolah sebagai orang yang bermasa depan suram, dan yang dapat lulus dengan predikat yang baik maka akan disebut sebagai bermasa depan cerah. Pengetahuan adalah sumber keberhasilan, dan "permulaan dari pengetahuan adalah takut akan Tuhan" (Ams. 1:7) dan “...karena terang hanya berbuahkan kebaikan dan keadilan dan kebenaran,..." ayat 9, demikianlah hendaknya ditanamkan dalam setiap pribadi peserta didik agar senantiasa belajar dengan giat.

Dari hasil pemaparan setiap point dari ayat ke-3 hingga ke-10 ini, penulis menyimpulkan bahwa lingkungan yang sehat menunjang perkembangan karakter bijak. Hal ini sesuai dengan apa yang menjadi pokok pikiran Paulus dalam Efesus 5:3-10, sebab dari lingkungan yang sehat. Sehat secara harafiah dalam hal kebersihannya maupun sehat dalam makna implisitnya yang berarti secara pergaulan dan kondusifitasnya sebagai lingkungan belajar, yang mana mengajarkan kepada peserta didik untuk menghindari pergaulan yang buruk dan menyesatkan. Sehat berguna untuk bijak dalam menerima setiap pengajaran yang diberikan kepadanya dalam artian kritis dan selalu mengujinya terlebih dahulu sebelum menerapkannya dalam kehidupan: apakah hal tersebut sesuai dengan ajaran alkitab dan kebenaran Kristen.

\section{Memanfaatkan Waktu untuk Hal-hal yang Bermanfaat}

Pada ayat ke-11, dengan gamblang Paulus menyatakan agar orang Kristen jangan turut ambil bagian dalam perbuatan yang tidak menghasilkan apa-apa. Hal ini jelas mengacu pada perihal pemanfaatan waktu produktif supaya dipergunakan sebaik mungkin untuk hal-hal yang bermanfaat, dan bukannya untuk hal-hal remeh dan sia-sia yang mana akan membuang waktu berharga. Dalam hal ini mengenai peserta didik erat kaitannya dengan waktu belajar, baik di sekolah maupun di rumah agar jangan sampai peserta didik Kristen menghabiskan waktu berharganya untuk perkara-perkara yang tidak menghasilkan apa-apa. Misalkan game, dan keluyuran bermain yang justru membuatnya lalai mengerjakan tugasnya.

Lebih serius, Paulus menyatakan di ayat 12 , “...menyebutkan sajapun apa yang dibuat oleh mereka di tempat-tempat yang tersembunyi telah memalukan.." Bahkan untuk menyebutkan hal yang dilakukan orang-orang bebal, yang mereka lakukan di 
tempat-tempat tersembunyi pun, merupakan suatu tindakan yang memalukan, lalu bagaimana jika hal yang sebegitu hina tersebut apabila sampai dilakukan oleh orang percaya, atau dalam hal ini yang dimaksud adalah pelajar. maka dari itu, hendaklah pelajar Kristen senantiasa menjaga dirinya agar jangan sampai akibat kelalaiannya Allah dipermalukan.

Sungguh merupakan berkat yang perlu disyukuri apabila hal ini disadari oleh setiap peserta didik yang belajar mengenai Alkitab, bahwa Allah telah memberi tuntunan untuk setiap perkara yang akan manusia jumpai dalam kehidupan. Hal tersebut seperti di ayat ke-14, melalui hambanya yaitu Paulus kepada jemaat di Efesus dan sebagaimana berlaku juga bagi umat Allah masa kini. Allah membangkitkan orang Kristen dari kematian melalui pengorbanan Yesus, putra-Nya yang tunggal sebagai penebus bagi dosa-dosa manusia, supaya yang percaya kepada-Nya memperoleh keselamatan. Oleh karenanya patutlah apabila setiap pelajar Kristen menyerahkan hidup yang seutuhnya sebagai persembahan yang hidup, tidak hidup seperti orang bebal, melainkan seperti orang arif, dan menggunakan waktu hidupnya untuk mengusahakan perkara-perkara yang melaluinya nama Allah dipermuliakan.

Efesus 5:17-21 memberikan tuntunan agar hidup manusia lebih terarah. Ayat 17 diawali dengan kalimat "Sebab itu janganlah kamu bodoh, tetapi usahakanlah supaya kamu mengerti kehendak Tuhan." Kata "bodoh" berasal dari kata Yunani afrones yang diartikan "bodoh," "tolol," "tidak bijak," dan "tidak terpelajar.",38

${ }^{38}$ Gerhard Kittel, Gerhard Friedrich, Geoffrey W. Bromiley, Theological Dictionary of the New Testament: abridged in one volume (Grand Rapids, Michigan: Wm. B. Eerdmans Publishing, 1985), 1278.
Lawan dari kebodohan pada ayat ini bukanlah kejeniusan berpikir melainkan mengerti kehendak Tuhan. Ini tentunya terkait dengan konteks perikop yang sejak awal membandingkan antara yang terang dan yang gelap, antara dulu dan sekarang, lalu antara yang bodoh dan mengerti. Phrashnig menyatakan bahwa sebagai pelajar, seorang anak perlu berjuang, selain mencari hal yang berguna bagi kehidupannya, mengerti kehendak Tuhan atas dirinya, dan menghindari pengaruh buruk yang sering berasal dari temantemannya di sekolah maupun di lingkungan rumah. ${ }^{39}$

Ayat 18 berbunyi "Dan janganlah kamu mabuk oleh anggur, karena anggur menimbulkan hawa nafsu, tetapi hendaklah kamu penuh dengan Roh." Ada masa ketika pelajar diperhadapkan pada kesempatan pertemanan yang salah. Teman-temannya mengajak untuk melakukan tindakantindakan yang menjerumuskan, seperti merokok, minum minuman keras, mengonsumsi obat-obatan yang terlarang dan hal-hal lain yang dapat menghancurkan masa depan seorang pelajar. Pelajar harus menggunakan waktunya untuk hal-hal bermanfaat, menambah ilmu pengetahuan dan menguasai teknologi terkini. Zaman akan terus berubah, persaingan di dunia, baik persaingan prestasi belajar maupun persaingan kerja mengharuskan seorang pelajar untuk bersikap bijak menggunakan waktunya.

Hal bermanfaat bagi roh dan jiwa manusia disampaikan pada ayat 19. Bernyanyi dan bersoraklah bagi Tuhan dengan segenap hati, pada ayat yang ke-19

\footnotetext{
${ }^{39}$ Barbara Prashnig, The Power of Learning Styles: Mendongkrak Anak Melejitkan Prestasi dengan Mengenali Gaya Belajarnya (Bandung: Kaifa, 2007), 137.
} 
mengacu pada nasihat untuk bertutur-kata yang baik, dan tidak menyakiti lawan bicara, serta melalui perkataan injil semakin dikenal dan disebarluaskan sehingga Amanat Agung untuk menjadikan semua bangsa sebagai murid tercapai. Kaum muda pada umumnya suka memainkan musik dan bernyanyi. Para pelajar Kristen khususnya perlu dimotivasi dan difasilitasi untuk mengembangkan bakatnya di bidang musik dan vokal. Mereka dapat mengambil bagian dalam liturgi sebagai pelayan Tuhan di bidang musik dan pujian. Makna iman dan perasaan tidak cukup hanya diungkapkan melalui kata-kata, melalui puji-pujian ruang spiritual dan kesadaran tentang kebesaran, kuasa dan kasih Tuhan diperkaya.

\section{KESIMPULAN}

Makna cintai lingkungan adalah kewajiban semua orang, lebih khusus dalam lingkungan pendidikan. Hal ini perlu ditanamkan kepada peserta didik agar bertumbuh menjadi generasi yang dapat ambil bagian dalam rangka melestarikan lingkungan alam maupun lingkungan pergaulan, sehingga tercipta lingkungan kehidupan yang sehat untuk menunjang perkembangan masyarakat yang berakhlak mulia dan berwawasan ekologi yang baik.

Sebagai terhadap cinta lingkungan adalah ketaatan untuk mewujudkan upaya pelestarian lingkungan (keluarga, sekolah, dan masyarakat) adalah dengan ketaatan terlebih dahulu. Ketaatan tersebut haruslah berdasarkan pada kasih, karena dengan mengasihi, manusia akan dengan otomatis memiliki rasa peduli. Ketiga lingkungan tersebut sebagai wadah pembentukan karakter seseorang. Nilai-nilai yang hidup dalam masyarakat dan terbentuk dalam suatu sistem nilai yang menjadi sumber rujukan dalam pembentukan pribadi atau karakter anak lebih baik. Dengan demikian ketaatan tersebut dapat menunjang efektifitas pembelajaran setiap orang.

Tidak ada teladan yang lebih baik dari pada Kristus sendiri dalam hal mengasihi, maka dari itu, orang Kristen harus mendekatkan diri lebih lagi kepada Kristus dan menyelami apa yang menjadi kehendak Tuhan atas diri masing-masing, lalu menerapkan kasih Kristus kepada lingkungan, agar tercipta lingkungan yang sehat dan penuh kasih di dunia pendidikan Indonesia. Dengan demikian, orang Kristen yang menerapkan cinta lingkungan berarti juga mempraktikan nilai-nilai religious yang dianutnya.

\section{DAFTAR PUSTAKA}

Abineno, J.L.Ch. Tafsiran Alkitab: Surat Efesus. Jakarta: Gunung Mulia, 2003.

Anwar, M. Filsafat Pendidikan. Jakarta: Kencana, 2015.

Fraenkel, Jack R. Helping Students Think and Value: An Analytic Approach. New Jersey: Prentice Hall, 1977.

Harjali, Penataan Lingkungan Belajar: Strategi untuk Guru dan Sekolah. Malang: Seribu Bintang, 2019.

Hasbullah, Dasar-Dasar Ilmu Pendidikan. Jakarta: Raja Grafindo Persada, 2009.

Kementerian Kesehatan RI. Pusat Data dan Informasi. J Infodatin, "Reproduksi Remaja," diakses 20 Maret 2020, https://www.depkes.go.id.

Kittel, Gerhard, Gerhard Friedrich, Geoffrey W.Bromiley, Theological Dictionary of the New Testament: abridged in one volume. Grand Rapids, Michigan: Wm. B. Eerdmans Publishing, 1985.

Mansur, Rosichin. "Lingkungan Yang Mendidik Sebagai Wahana Pembentukan Karakter Anak" Vicratina: Jurnal Pendidikan Islam 
2, no. 2 (July 4, 2018):33-46.

Moeliono, M. Anton. Tata Bahasa Baku Bahasa Indonesia. Jakarta: Balai Pustaka, 1993.

Nahdi, Khirjan. Pendidikan dan Modernisasi Peradaban. Yogyakarta: Cakrawala, 2018.

Nata, Abudin. Ilmu Pendidikan Islam. Jakarta: Kencana Prenada Media Group, 2010.

Neolaka, Amos, and Grace Amialia A. Neolaka. Landasan Pendidikan Dasar Pengenalan Diri Sendiri Menuju Perubahan Hidup. 1st ed. Jakarta: Kencana, 2015.

Purwanto, Ngalim. Psikologi Pendidikan. Bandung: Remaja Rosdakarya, 2000.

Phrashnig, Barbara. The Power of Learning Styles: Mendongkrak Anak Melejitkan Prestasi dengan Mengenali Gaya Belajarnya. Bandung: Kaifa, 2007.

Prasasti, Giovanni Dio. "Riset: 33 Persen Remaja Indonesia Lakukan Hubungan Seks Penetrasi Sebelum Nikah," Liputan6.com, diakses 20 Maret 2020,

https://www.liputan6.com/health/rea d/4016841/riset-33-persen-remajaindonesia-lakukan-hubungan-sekspenetrasi-sebelum-nikah\#.

Rianawati. Implementasi Nilai -Nilai Karakter Pada Mata Pelajaran. IAIN Pontianak Press, 2014.

Rosana, Dadan. "Berbagai Model Dan Metode Pembelajaran Aktif Kreatif Dan Inspiratif Bagi Keberhasilan Belajar Siswa," last modified March 29, 2020,

http://staffnew.uny.ac.id/upload/132 058092/lainlain/ makalah-ppsb-man3.pdf.

Schultz, Duane. Psikologi Pertumbuhan, Model-Model Kepribadian Sehat. Yogyakarta: Kanisius, 1991.

Siska, Yulia. Geografi Sejarah Indonesia.
Garudhawaca, 2018.

Subianto, Jito. "Peran Keluarga, Sekolah, Dan Masyarakat Dalam Pembentukan Karakter Berkualitas" Jurnal Edukasia, Vol. 8, No. 2, (2013): 331-354.

Sukarman, "Reaktualisasi Konsep Tri Pusat Pendidikan Ki Hajar Dewantara dalam Perspektif Pendidikan Islam Bagi Generasi Milenial" Jurnal Progress: Wahana Kreativitas dan Intelektualitas Vol. 5 No. 1 (2017):124.

Sukiyat, Strategi Implementasi Pendidikan Karakter. Surabaya: Jakad Media Publishing, 2020.

Suprihatiningsih, Perspektif Manajemen Pembelajaran Program Keterampilan. Yogyakarta: Deepublish, 2016.

Suyanto dan Asep Jihad, Menjadi Guru Profesional: Strategi Meningkatkan Kualifikasi dan Kualitas Guru di Era Global. Jakarta: Penerbit Erlangga, 2013.

Taylor, John. Greek to GCSE: Part 2: Revised Edition for OCR GCSE Classical Greek (9-1). Bloomsbury Publishing, 2016.

Tridonanto, Al. Menjadikan Anak Berkarakter. Jakarta: Elex Media Komputindo, 2013.

Wibawa, Made Aripta. Siapakah yang Disebut Guru: Suatu Kajian Theologis dan Sosiologis. Denpasar: Panakom Pub., 2005.

Wijayakusuma, Hembing. Selamatkan Umat Manusia dari Kebinasaan. Jakarta: Pustaka Kartini, 1995. 